\title{
A Framework for Evaluating Information Transparency in Supply Chains
}

\author{
Erhan Ada, Yasar University, Bornova, Turkey \\ iD https://orcid.org/0000-0002-4439-0966 \\ Muhittin Sagnak, Izmir Katip Celebi University, Izmir, Turkey \\ (iD) https://orcid.org/0000-0002-0799-0348 \\ Yigit Kazancoglu, Yasar University, Bornova, Turkey \\ (iD) https://orcid.org/0000-0001-9199-671X \\ Sunil Luthra, Ch. Ranbir Singh State Institute of Engineering and Technology, Panakeso, India \\ iD https://orcid.org/0000-0001-7571-1331 \\ Anil Kumar, London Metropolitan University, UK
}

\begin{abstract}
Private, public, profit, and non-profit organizations and society as a whole currently face a significant reliable information necessity problem. Especially supply chains need trustworthy information to perform their activities successfully. This study aims to propose a framework and identify how reliability of information can be evaluated and measured through the concept of transparency. In this context, dimensions such as comprehensiveness, regularity, timeliness, content, scope, and userfriendliness are the pillars of the proposed framework. Selected criteria have been used as inputs to develop the information transparency level. The fuzzy analytic network process (ANP) is used to obtain weights of these inputs, and data envelopment analysis (DEA) is used for the determination of the efficiency ranking for transparency. Results demonstrated that content, scope, and comprehensiveness dimensions have $75 \%$ impact on the transparency of data. The remaining $25 \%$ is affected by timeliness, regularity, and user-friendliness.
\end{abstract}

\section{KEYWORDS}

Data Envelopment Analysis, Framework, Information Transparency, Measurement, Supply Chain Management

\section{INTRODUCTION}

Today, the global economy forces companies about improving the manufacturing sector in terms of sharing and spreading in present-day conditions. Thus, appropriate information and knowledge are needed for companies to survive and complete this process (Dev et al., 2013; Hung et al., 2014). Information flow has become the most substantial factor by identifying the difference among the organizations for the rapidly changeable business environment and market conditions (Sahin \& Topal, 2019).

Information flow can be achieved by the sharing of information. Concordantly, information sharing, and technologies are one of the most crucial components for coordinated supply chain parties 
(Kumar \& Pugazhendhi 2012). Although, it is not easy to adopt information sharing in the supply chains (Hung et al., 2014), it is an inbuilt part of the integrated supply chain management (Hung et al., 2011). Therefore, information sharing plays a vital role in achieving the 3Cs of supply chain management which are cooperation, collaboration (Wood et al., 2017) and coordination (Maskey et al., 2019). Businesses can develop the transparency of their supply chain through the information and knowledge sharing and manufacturing infrastructure as the most crucial elements (Narwane et al., 2020). From the point of the supply chain, transparency appeals to the available information that is accessible to the companies included in a supply chain network (Minami et al., 2012). Traceability feature of the supply chain strengthens the transparency to make organizational goals operational relevant to the feedstock origins and provide a source for finished product and service.-Supply chain management requires a level of transparency between supply chain members about product quantities and characteristics that need to be delivered to markets (Wood et al., 2017). The transparency concept of the supply chain incorporates the easily convenient information to end-users and firms within the supply chain (Francisco \& Swanson, 2018).

Over the past twenty years, according to the given attention to the institutional issues e.g. corruption and the rule of law and so on, the lack of broadly accepted index about transparency is quite confusing because transparency has an expansive extent throughout countries and time (Williams, 2015). This is also compatible with the research question of the Beulens et al., (2005) study which investigates how to measure information transparency. Hence, the motivation of this study is to reveal on how to manage and measure information transparency in supply chains. Therefore, there is a need to investigate how the information transparency can be analyzed and further categorized in a comprehensive manner. Meanwhile, it is noteworthy to scrutinize the methods to hire in measuring the information transparency. In that sense, the following research questions have been depicted.

RQ1: What are the dimensions and parameters to be considered in assessing information transparency of a company?

RQ2: Which solution method can enable companies to measure and compare the information transparency of other companies or suppliers among their supply chain?

In that sense, related to the first research question, there is a need to construct a framework in order to act as a reference point in assessing and more specifically in measuring the information transparency of companies. In addition, in accordance with the second research question, the managers need to implement the measuring of information transparency with analytical tool which may act as a decision support tool in managing supply chains from information perspective. Therefore, the following research objectives are stated:

- To construct a detailed framework embracing the all related aspects of measuring information transparency.

- To propose a framework that can enable managers to track, manage and benchmark the information transparencies of their suppliers in their supply chain.

Therefore, the main contribution of the study is to present a new comprehensive framework to measure the level of information transparency. In this study, relevant criteria set have been used as inputs to develop the information transparency level. The proposed framework comprises 43 inputs in order to measure the information transparency level in a sense of six dimensions as follows: comprehensiveness, regularity, timeliness, content, scope, and user-friendliness. Moreover, these 43 inputs have been used as inputs to develop the information transparency level. Thus, the second contribution of the study is to propose DEA to measure the transparency of companies and therefore a case study have been conducted in food industry. For this purpose, the Fuzzy Analytic Network 
Process (ANP) has been used to obtain the related weights of these 43 inputs. Then, Data Envelopment Analysis (DEA) has been used to determine the prioritization of alternatives regarding information transparency scores of companies in terms of efficiency ranking.

Following the introduction, section 2 shows the theoretical background, and section 3 identifies how to measure transparency and the proposed framework. Methodology is described in Section 4. Section 5 summarizes the case study, and the results and findings, and section 6 presents the discussions and implications. Finally, section 7 highlights the concluding remarks.

\section{THEORETICAL BACKGROUND}

Transparency has become regarded as an essential for the democratic participation, reliance to government, an obstacle to corruption, knowledge-based decision-making and providing information to the public, firms and other society functions (Cullier \& Piotrowski, 2009; Mulgan, 2007; Quinn, 2003; Reylea, 2009; Shuler et al., 2010). Over the past decade, the social, political, and economic significance of transparency has increased among academics and practitioners alike (Williams, 2015).

The meaning of transparency can diversify among the different groups and it could be substantial for various ways (Williams, 2015). So, it can be inferred as the extent of related, timely, and dependable information in a written and verbal manner, which the organization provides to investors, regulators, and market intermediaries (Williams, 2005). Florini (2000) provides an extensive perception of the related subject. According to this opinion, transparency means the distribution of information through the organizations which are relevant for the assessment of those organizations. Due to these institutions are respected as either public or private, it presents a good initial point. This looseness obviously comes from the applicability of the transparency to various fields such as institution management, national security, national budgets, international institutions, etc. In a definition that has been widely used (Williams, 2015). Stiglitz (2000) presents a description where the transparency is simply else named for information. Therefore, an increase in transparency is required to reduce and minimize informational asymmetries in the market. Lazarus \& McManus (2006) defined the concept of transparency in an interview as open and accessible information, information free-flow, and the right to reach information (Al-Jabri \& Rostocki, 2015).

Information transparency prevails when an internal worker obtains the required information, at their desktops, to make a strategic decision in a corporate and organizational environment (Simon, 2006). Street \& Meister (2004) discussed the two separate information transparency types which are internal and external information transparency. Their description of internal transparency is defining it as a communication output in an organization that represents which employees have accessibility to the information that is a necessity to fulfill their duties and responsibilities. In comparison with internal transparency, external transparency can be determined as a communication output which is oriented outside of the organization (Bushman et al., 2004). Literature about business ethics has created a transparency concept that defines transparency as a mechanism that is required to foster reliance, fairness, and prudence (Das Neves and Vaccaro, 2013), and transparency concept has been debated as a strategic revealing process which causes organizational legitimacy and reduces corruption in the area of corporate social responsibility (Coombs \& Holladay, 2013). Thus, transparency is widely assumed as a tool to manage reputation and a way to show reliability in research studies about management.

Transparency can be evaluated from two standpoints (Bach et al., 2015). The first one points out to the transparency's positive effect on reputation. Thereby, there is a concerted fact about the need for an organization's operations to be comprehended in an open and right way by society for the purpose of improving the company image. In this sense, organizational transparency can be a corporate tool for communication that seeks to locate the brand in a way that can be socially responsible, presenting to its internal or external stakeholders, its social devotion depending on altruistic values (Bigné et al., 2010). The second view for the analysis of business transparency debates that transparency is more than a tool or mechanism in order to make a positive image and keep in good with the society. So, 
it can be an important organizational technique which enables the businesses to attain and sustain the competitive advantage by generating a value for the society as a whole (Porter \& Kramer, 2011).

An increasing information transparency degree can contribute to much better choices and eventually increased work satisfaction. Therefore, it can be discussed that a higher transparency degree, based upon the data and information sharing result in from the application of information system e.g. ERP, can cause a good sensation about the benefit and ease of handling; and creates a convenient attitude and successive adoption of information technology (Al-Jabri \& Rostocki, 2015).

Supply chain network transparency can be identified as a scope of sharing and accessing information related to product and process by all network's stakeholders that they claim, no loss, noise, delay, and corruption (Beulens et al., 2005). Information is becoming more transparent in e-enabled organizations because of the exchange of a vast amount of information among the buyers, sellers, and competitors (Al-Jabri \& Rostocki, 2015).

According to the description given in above, it can be deduced that functionality is a requirement that needs to achieve in information transparency by incorporating the shared provision of useful data via the base of the system by partners (Beulens et al., 2005). It indicated that organizational and even psychological issues tented to present significant challenges for the creation of the SCN level transparency such as the risk of unchartered information usage, cost apportionment and compensation rules in terms of calamities, uncertainty about the actualization and extra profits out of the projects, obscurity on cost savings, independency loss (Beulens et al., 2005).

Supply chain transparency could be identified as an extent of accessing the process, product, and capital flow without delay, distortion, and loss, related information to which supply chain player (Beulens et al. 2005). Access to the information in a transparent supply chain is easy and fast. Besides, information needs to be revealed in an understandable, extensive, credible, and rapid manner to the important member of the supply chain e.g. buyers, regulatory and supervisory authorities, or stockholders (Bastian \& Zentes, 2013; Trienekens et al. 2012; Wognum et al. 2011). Bartlett et al. (2007) illustrate that improved transparency contributes to stronger performance because improved transparency led them to plan faster and better results from the visibility of their effect on the supply chain. In addition to these advantages, organization and the users will earn trust from the transparency or disclosure of the information (Rawlins, 2008), better management (Chi, 2009), outstanding effort and performance (Berggren \& Bernshteyn, 2007), escalated manufacturing efficiency (Zhu, 2002), and enhanced organizational learning (Kumaraswamy \& Chitale, 2012). Therefore, a decrease in the number of supply chain tiers and members can be an effective and efficient instrument in order to reduce the confusion and develop supply chain transparency (Bastian \& Zentes, 2013). Moreover, transparency may assist to reduce the asymmetry in the information among the supplier and the buyer/retailer together with the stockholders via using tools e.g. product information systems, codes of conduct, and certification programs (Boström et al., 2015). Higher transparency in information would increase the efficiency of SC partnerships and contribute to a growth in SC partnership (Khan et al., 2019).

Worldwide, all organizations and firms, profit, and nonprofit, are under growing pressure in order to be transparent (Khan et al., 2019). The motivation of the industry is about the transparency is dividing into four: Firstly, enterprises are obliged to submit ever-changing consumer demands from as legislative demands. Secondly, in case of incidents, companies need to be ready and be able to recall the product as soon as possible from the market or link downstream the supply chain for restricting the incidents and for minimizing the cost. Thirdly, optimization of the business process can be much simpler when the attribution of the product and process is connected with the performance of the process through developing the flow of information across integrated information systems. Lastly, being interested and labeling products depending on differentiating product attributes, as intrinsic and extrinsic, is an essential approach for the companies in terms of adding value (Trienekens et al., 2012).

Alongside these benefits, there are also disadvantages. For the purpose of increasing transparency of information, partners generally need to invest a vast sum of money in order to develop the 
information system and improve information circulation. Furthermore, from the point of partners, some of the concerns about the information transparency are about releasing confidential information that can result in a competitor attack. Thus, some of the partners might be unable to share out their information that can cause to fragmental information transparency. It can be deducted from the above that the leaders of the supply chain typically adopting absolute dominance in order to strive for every supply chain partner for information transparency. Although high investment costs can lead some hesitation in the partner, that will cause partners to ask themselves to the question that is these investment costs are really required. The control of the investment cost in information systems can alleviate the interaction among information transparency and capability to adjust and redeliver resources (Shi et al., 2019). Moreover, the management will eventually want to measure and control the degree that they achieved so far with an over costing transition into information transparency and compare their efficiency with the other stakeholders of the supply chain.

Also, as Williams (2015) has mentioned the absence of no commonly accepted system for measuring transparency which has a wide extent over both countries and time. For the purpose of reaching a concurrence about data transparency, developing a framework despite the complex structure of big data is necessary. Dimensions about data transparency, measurement of transparency, data processing technologies, and infrastructure of the relevant bodies, e.g. centers or agencies, needs to be studied in detail for the development of an appropriate framework about data transparency. In the literature, many related studies focus on different aspects of framework development. The concept of the "Transparency Score" is developed for the measurement of transparency to identify how much transparency that may have to be qualified about an item of given data or data group items is available for the user. "Transparency score" is computed, similar to the risk scores of security and privacy, which can include a vector, or scalar risk measures for transparency, and several dimensions of transparency (Bertino et al., 2019b).

\section{PROPOSED FRAMEWORK}

In the literature, there have been studies concerning transparency indices. Some of them tried to measure the transparency, whereas others calculated the particular aspect of it (Williams, 2015). Coronel (2012) claimed that there is no generally acceptable transparency index in global scope; instead, the transparency indices used different set of criteria and methodologies, and were developed according to the country-specific properties.

Islam (2006) considered the transparency of economic components as well as the presence or lack of the Freedom of Information Laws. Williams (2009), and Hollyer et al. (2011) took the same approach by considering the amount of data that governments released. Framework design for data transparency entails an in-depth study to determine possible dimensions. The five crucial data transparency dimensions were stated by Bertino et al. (2019a): Record Transparency, Use Transparency, Disclosure and Data Provisioning Transparency, Laws and Policies Transparency, and Algorithm Transparency; and then two more dimensions have been added by Bertino et al. (2019b) as AI Ethics Transparency, and Breach Transparency. Record Transparency refers to information collected based on; context, collection agent, and data storage whereas Use Transparency is defined as the identity of the user and use of purpose. Disclosure and Data Provisioning Transparency is stated as the release of data and data delivery based on technical transferring tools. Laws and Policies Transparency is defined by the legal aspects of the data transparency. Algorithm Transparency refers to the basic information about the algorithms used in decision making processes. AI Ethics Transparency is stated as the relation to ethical concerns of the data use. Finally, Breach Transparency is explained by the time and method of breech, the features of the information that were breached, and consequences of the breech (Bertino et al., 2019a; 2019b). However, none of them considered a comprehensive and holistic structure to deal with information transparency in supply chains. 
In this study, a framework was proposed to measure information transparency. It covers the definition of information transparency measures, structuring the main and sub-dimensions of measures, and adopting Data Envelopment Analysis by using the criteria as inputs. Proposed framework includes 6 main inputs, namely, comprehensiveness, regularity, timeliness, content, scope, and userfriendliness, and 43 inputs. The proposed framework and the DEA method are implemented in an organization to measure the level of information transparency with its suppliers. Figure 1 show the proposed framework.

Systematicness is about how systematic the data are collected. Comprehensiveness and regularity of data should be considered to understand the level of systematicness of the data. The comprehensiveness of data disclosure is identified by the amount of data actually published compared to the amount that needs to be published. The regularity of the data is determined by how consistent the disclosure program is.

Timeliness refers to timing of data published. The timeliness of data is identified by local pollution-source information.

Completeness is about how complete the data are collected. In order to evaluate how complete the data, content, and the scope of the published information about the sources and the published information were identified.

User-friendliness is about how user-friendly the data are collected. In order to evaluate how user-friendly the data are, the easiness of obtaining data and its appropriateness for an internet user is evaluated.

Therefore, the input set includes 6 main dimensions, comprehensiveness, regularity, timeliness, content, scope, and user-friendliness.

For measuring information transparency, the criteria set, in other words, input set is determined based on 4 main dimensions, namely, systematicness, timeliness, completeness, and user-friendliness (PITI, 2018).

Table 1 shows the criteria set, in other words, proposed inputs for information transparency and the relationships of dimensions of transparency as follows:

Each asterisk shows the relation in terms of information transparency. For instance, accessibility of data is one of the inputs that affects the level of information transparency, and in a relationship with regularity and user-friendliness score.

Complexity of data, cost of data, information asymmetry, missingness of data, volatility of data, and vulnerability of data are the cost criteria, whereas, others are benefit.

For validation, the proposed inputs and transparency dimensions relationship is discussed with 5 authorities, who can be determined as experts due to their experience $(20,17,16,15$, and 12 years, respectively). Table 2 shows information about company experts.

\section{METHODOLOGY}

Each input in the input set does not have same importance level while determining the information transparency. Therefore, in this paper, Fuzzy Analytic Network Process (ANP) is used to obtain the relative weights of inputs. Then, Data Envelopment Analysis (DEA) is used for prioritization of alternatives regarding information transparency scores of companies in terms of efficiency ranking. The reason to hire fuzzy logic is its capability to eliminate the uncertainties and vagueness inherent in decision-making process. The reason to select FANP is that it is one of the most common multicriteria decision-making (MCDM) techniques to calculate the weights of different criteria. The reason to use DEA is the ability to rank the alternatives through an optimization model, and react successfully when there are many alternatives. 
Figure 1. The Proposed Framework

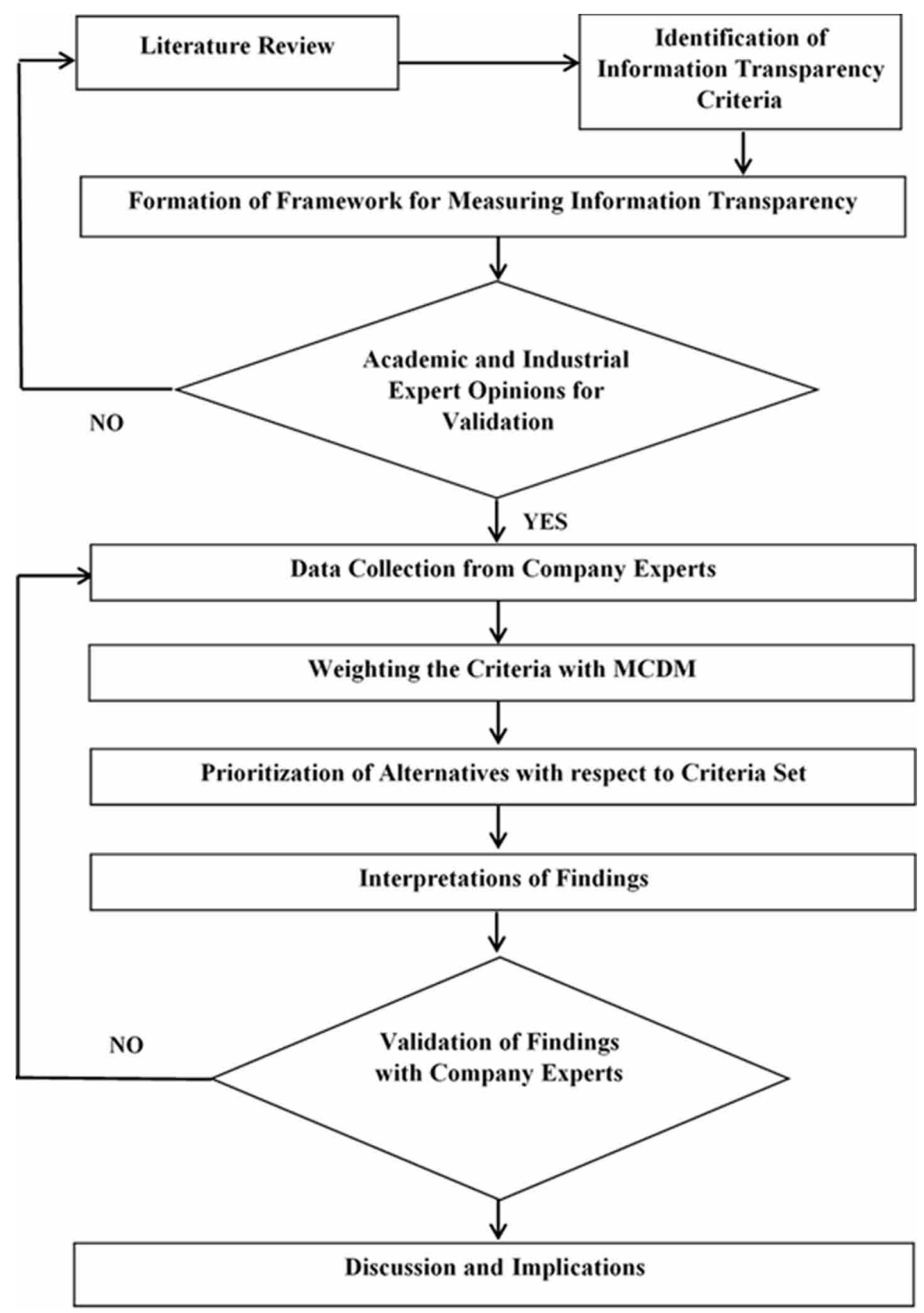

\subsection{Fuzzy Analytic Network Process (FANP)}

Analytic Network Process (ANP) was proposed by Saaty (1996). It is one of the most common MCDM techniques. Its main advantage is its capability to cope with qualitative and quantitative variables (Sagnak and Kazancoglu, 2019). However, its applicability is limited due to the uncertainties and vagueness inherent in decision-making process (Kazancoglu et al., 2020). Therefore, in this study, ANP was integrated with fuzzy set theory.

Fuzzy ANP is different with Saaty's (1996) approach (Kazancoglu et al., 2020). Pairwise comparisons were carried out using triangular fuzzy numbers. Saaty's (1980) scale has advantages in terms of simplicity; however, using fuzzy numbers instead of crisp values to translate human 
Journal of Global Information Management

Volume 29 • Issue 6

Table 1. Proposed Inputs and Transparency Dimensions Relationship

\begin{tabular}{|c|c|c|c|c|c|c|c|}
\hline Inputs & Comprehensiveness & Regularity & Timeliness & Content & Scope & $\begin{array}{l}\text { User- } \\
\text { friendliness }\end{array}$ & Source \\
\hline $\begin{array}{l}\text { Accessibility } \\
\text { of data }\end{array}$ & & * & & & & $*$ & $\begin{array}{l}\text { Oweis \& Dekhili, } \\
\text { 2019; Wang et al., } \\
2019\end{array}$ \\
\hline $\begin{array}{l}\text { Accuracy } \\
\text { of data }\end{array}$ & & & * & * & * & & $\begin{array}{l}\text { Hollyer et al., } \\
\text { 2014; Maskey et } \\
\text { al., 2019; Oweis \& } \\
\text { Dekhili, } 2019\end{array}$ \\
\hline $\begin{array}{l}\text { Adequacy } \\
\text { of data }\end{array}$ & & & & * & * & & $\begin{array}{l}\text { Maskey et al., } \\
\text { 2019; Oweis \& } \\
\text { Dekhili, } 2019\end{array}$ \\
\hline Audited data & & * & & * & * & & $\begin{array}{l}\text { Hollyer et al., } \\
\text { 2014; Wang et al., } \\
2019\end{array}$ \\
\hline $\begin{array}{l}\text { Authentication } \\
\text { of data }\end{array}$ & & & & $*$ & & & Wang et al., 2019 \\
\hline $\begin{array}{l}\text { Chronological } \\
\text { situation of data }\end{array}$ & * & & * & & & & Wang et al., 2019 \\
\hline $\begin{array}{l}\text { Comparability } \\
\text { of data }\end{array}$ & & $*$ & $*$ & $*$ & $*$ & & $\begin{array}{l}\text { Oweis \& Dekhili, } \\
2019\end{array}$ \\
\hline $\begin{array}{l}\text { Compatibility } \\
\text { of data }\end{array}$ & & & $*$ & & & $*$ & Maskey et al., 2019 \\
\hline $\begin{array}{l}\text { Complexity } \\
\text { of data }\end{array}$ & * & & & $*$ & $*$ & $*$ & $\begin{array}{l}\text { Hollyer et al., } \\
\text { 2014; Maskey et } \\
\text { al., 2019; Wang et } \\
\text { al., } 2019\end{array}$ \\
\hline Cost of data & * & & & & & $*$ & $\begin{array}{l}\text { Hollyer et al., } \\
\text { 2014; Maskey et } \\
\text { al., 2019; Wang et } \\
\text { al., } 2019\end{array}$ \\
\hline $\begin{array}{l}\text { Credibility } \\
\text { of data }\end{array}$ & $*$ & & & * & $*$ & & $\begin{array}{l}\text { Hollyer et al., } \\
\text { 2014İ Maskey et } \\
\text { al., } 2019\end{array}$ \\
\hline $\begin{array}{l}\text { Criticality } \\
\text { of data }\end{array}$ & * & $*$ & * & * & * & & Hollyer et al., 2014 \\
\hline $\begin{array}{l}\text { Cryptography } \\
\text { of data }\end{array}$ & & $*$ & & * & & & Wang et al., 2019 \\
\hline Data integrity & * & & & $*$ & $*$ & & Wang et al., 2019 \\
\hline Data ownership & $*$ & $*$ & & & & & Wang et al., 2019 \\
\hline $\begin{array}{l}\text { Historicity } \\
\text { of data }\end{array}$ & & * & * & & & & $\begin{array}{l}\text { Our } \\
\text { Contribution }\end{array}$ \\
\hline $\begin{array}{l}\text { Decentralization } \\
\text { of data }\end{array}$ & $*$ & & & & $*$ & & Wang et al., 2019 \\
\hline $\begin{array}{l}\text { Dependability } \\
\text { of data }\end{array}$ & $*$ & & & & $*$ & & Maskey et al., 2019 \\
\hline $\begin{array}{l}\text { Digitization } \\
\text { of data }\end{array}$ & & $*$ & * & & & $*$ & Wang et al., 2019 \\
\hline $\begin{array}{l}\text { Disintermediation } \\
\text { of data }\end{array}$ & & & & * & $*$ & $*$ & Wang et al., 2019 \\
\hline $\begin{array}{l}\text { Information } \\
\text { Asymmetry }\end{array}$ & $*$ & & & $*$ & & & Wang et al., 2019 \\
\hline
\end{tabular}


Table 1. Continued

\begin{tabular}{|c|c|c|c|c|c|c|c|}
\hline Inputs & Comprehensiveness & Regularity & Timeliness & Content & Scope & $\begin{array}{l}\text { User- } \\
\text { friendliness }\end{array}$ & Source \\
\hline $\begin{array}{l}\text { Interaction } \\
\text { Routine } \\
\text { (Circulation) }\end{array}$ & & $*$ & $*$ & & & & Maskey et al., 2019 \\
\hline $\begin{array}{l}\text { Legalness } \\
\text { of data }\end{array}$ & $*$ & & & * & $*$ & & $\begin{array}{l}\text { Hollyer et al., } \\
\text { 2014; Maskey et } \\
\text { al., 2019; Oweis } \\
\text { \& Dekhili, 2019; } \\
\text { Wang et al., } 2019\end{array}$ \\
\hline $\begin{array}{l}\text { Legitimacy } \\
\text { of data }\end{array}$ & & & & * & $*$ & & Wang et al., 2019 \\
\hline $\begin{array}{l}\text { Missingness } \\
\text { of data }\end{array}$ & & & $*$ & $*$ & & & $\begin{array}{l}\text { Hollyer et al., } \\
\text { 2014; Maskey et } \\
\text { al., } 2019\end{array}$ \\
\hline Privacy & * & $*$ & & $*$ & & & $\begin{array}{l}\text { Maskey et al., } \\
2019 \text {; Wang et al., } \\
2019\end{array}$ \\
\hline $\begin{array}{l}\text { Relevancy } \\
\text { of data }\end{array}$ & & & $*$ & $*$ & $*$ & & $\begin{array}{l}\text { Hollyer et al., } \\
\text { 2014; Oweis \& } \\
\text { Dekhili, } 2019\end{array}$ \\
\hline $\begin{array}{l}\text { Reliability } \\
\text { of Data }\end{array}$ & & * & & $*$ & * & & $\begin{array}{l}\text { Maskey et al., } \\
\text { 2019; Oweis \& } \\
\text { Dekhili, 2019; } \\
\text { Wang et al., 2019 }\end{array}$ \\
\hline Security & & * & & $*$ & & & Wang et al., 2019 \\
\hline $\begin{array}{l}\text { Source } \\
\text { of data }\end{array}$ & $*$ & * & & & & & $\begin{array}{l}\text { Oweis \& Dekhili, } \\
2019 \text {; Wang et al., } \\
2019\end{array}$ \\
\hline $\begin{array}{l}\text { Speed of } \\
\text { Data Preparation }\end{array}$ & & & * & $*$ & & * & Hollyer et al., 2014 \\
\hline $\begin{array}{l}\text { Sufficiency } \\
\text { of data }\end{array}$ & $*$ & & & $*$ & $*$ & & Hollyer et al., 2014 \\
\hline $\begin{array}{l}\text { Traceability } \\
\text { of data }\end{array}$ & & $*$ & * & $*$ & & & $\begin{array}{l}\text { Maskey et al., } \\
2019 \text {; Wang et al., } \\
2019\end{array}$ \\
\hline $\begin{array}{l}\text { Trustworthiness } \\
\text { of data }\end{array}$ & & $*$ & & & $*$ & * & $\begin{array}{l}\text { Maskey et al., } \\
\text { 2019; Oweis \& } \\
\text { Dekhili, 2019; } \\
\text { Wang et al., 2019 }\end{array}$ \\
\hline $\begin{array}{l}\text { Understandability } \\
\text { of data }\end{array}$ & & & & $*$ & $*$ & $*$ & $\begin{array}{l}\text { Maskey et al., } \\
\text { 2019; Oweis \& } \\
\text { Dekhili, 2019; } \\
\text { Wang et al., 2019 }\end{array}$ \\
\hline Up-to-date & & $*$ & * & & & * & Our Contribution \\
\hline $\begin{array}{l}\text { Using real } \\
\text { time information }\end{array}$ & & $*$ & * & $*$ & & & Wang et al., 2019 \\
\hline $\begin{array}{l}\text { Validation } \\
\text { of data }\end{array}$ & & $*$ & & $*$ & & & Wang et al., 2019 \\
\hline $\begin{array}{l}\text { Verification } \\
\text { of data }\end{array}$ & & $*$ & & $*$ & & & Wang et al., 2019 \\
\hline $\begin{array}{l}\text { Versatility } \\
\text { of data }\end{array}$ & * & & & & & * & Maskey et al., 2019 \\
\hline $\begin{array}{l}\text { Volatility } \\
\text { of data }\end{array}$ & & $*$ & & * & * & & Maskey et al., 2019 \\
\hline
\end{tabular}


Table 1. Continued

\begin{tabular}{|l|l|l|l|l|l|l|l|}
\hline Inputs & Comprehensiveness & Regularity & Timeliness & Content & Scope & $\begin{array}{l}\text { User- } \\
\text { friendliness }\end{array}$ & Source \\
\hline & & & & & & & $\begin{array}{l}\text { Hollyer et al., } \\
2014 ; \text { Maskey } \\
\text { et al., 2019; } \\
\text { Oweis \& } \\
\text { Dekhili, 2019 }\end{array}$ \\
$\begin{array}{l}\text { Volume } \\
\text { of data }\end{array}$ & $*$ & & $*$ & $*$ & & & $\begin{array}{l}\text { Wang et al., } \\
2019\end{array}$ \\
\hline $\begin{array}{l}\text { Vulnerability } \\
\text { of data }\end{array}$ & & & & $*$ & $*$ & & \\
\hline
\end{tabular}

Table 2. Information about Experts for Validation

\begin{tabular}{|l|l|l|l|l|}
\hline Title/Position & Expertise & Faculty/Department & $\begin{array}{l}\text { Total Work } \\
\text { Experience in Years }\end{array}$ & Gender \\
\hline Academician & $\begin{array}{l}\text { Supply Chain } \\
\text { Management }\end{array}$ & Business & 20 & Male \\
\hline Academician & $\begin{array}{l}\text { Management } \\
\text { Information Systems }\end{array}$ & Business & 17 & Female \\
\hline Academician & Informatics & Engineering & 16 & Male \\
\hline Supply Chain Manager & Supply Chain & Supply Chain Dept. & 15 & Female \\
\hline Consultant & Management & Company Owner & 12 & Male \\
\hline
\end{tabular}

judgments into numerical values is always better option. The steps of Fuzzy ANP are as follows (Sagnak \& Kazancoglu, 2019; Yadav \& Singh, 2020):

Step 1: Establishment of Pairwise Comparisons: Pairwise comparisons were established to identify the relations among criteria.

Step 2: Formation of Initial Supermatrix: The initial supermatrix is formed to present the relative importance of cluster $\mathrm{k}$ to cluster 1 .

Step 3: Formation of Weighted Supermatrix: The weighted supermatrix is calculated through multiplying the first element of the respective eigenvector by all entries in the first block of that column, second element by second block, and so on.

Step 4: Formation of Limit Supermatrix: The limit supermatrix is calculated through taking power of weigthed supermatrix until all values for same row will be same.

Step 5: Normalization: The final weights can be found by the normalization process for each block of limit supermatrix.

\subsection{Data Envelopment Analysis (DEA)}

DEA is a linear programming model concentrating on calculating the efficiency of decision-making units (DMUs) depending on inputs and outputs correlated with DMUs. A DMU is known to be efficient if it receives the best output than its inputs. DEA was initially established by Charnes et al. (1978) and expanded by Banker et al. (1984) to provide variable returns to scale with BCC. The CCR contains both technical and scale inefficiencies while the distinction between technical and scale efficiency is performed by the BCC (Banker et al. 1984). Each model has two versions: inputoriented, and output-oriented. The input-oriented model emphasizes maximum movement across the frontier by proportional decrease of inputs, while the output-oriented model concentrates on maximum movement by proportional increase in outputs. 
CCR is the first and basic DEA model, and it focuses on the concept of efficiency (El-Mahgary, 1995). DEA-CCR calculating the efficiency of a DMU is calculated as the maximal rate of the weighted outputs to the weighted inputs, depending on the circumstances that the similar ratios for each DMU are smaller than or equivalent to the unity (Charnes et al. 1978). The model measures the total efficiency of the unit including its mere technical efficiency and scale efficiency (El-Mahgary, 1995). The CCR model yields in a piecewise linear, constant returns-to-scale envelopment surface (Ozden, 2008). BCC model is created by Banker et al. (1984). The BCC model measures technical efficiency as a convexity constraint (El-Mahgary, 1995). BCC model yields in a piecewise linear, variable returns-to-scale envelopment surface and (Ozden, 2008). In this paper, DEA BCC inputoriented model is used.

\subsubsection{DEA BCC Input-Oriented Model}

Objective Function

$\max h_{o}=\sum_{r=1}^{p} u_{r} Y_{r k}-\mu_{0}$

Constraints

$\sum_{i=1}^{m} v_{i} X_{i k}=1$

$\sum_{r=1}^{p} u_{r} Y_{r j}-\sum_{i=1}^{m} v_{i} X_{i k}-\mu_{0} \leq 0$

$u_{r} \geq \varepsilon$

$v_{i} \geq \varepsilon$

$\mu_{0}:$ unconstrained

$j=1, \ldots, \mathrm{n} i=1, \ldots, \mathrm{m} r=1, \ldots, \mathrm{p}$

$u_{r}: \mathrm{r}^{\text {th }}$ output is weighted by DMU of $k$,

$v_{i}: \mathrm{i}^{\text {th }}$ input is weighted by DMU of $k$,

$X_{i k}: \mathrm{i}^{\text {th }}$ input is used by DMU of $k$,

$Y_{r k}: \mathrm{r}^{\text {th }}$ output is produced by DMU of $k$,

$X_{i j}: \mathrm{i}^{\text {th }}$ input is used by $\mathrm{j}^{\text {th }} \mathrm{DMU}$,

$Y_{r j}: \mathrm{r}^{\text {th }}$ output is produced by $\mathrm{j}^{\text {th }} \mathrm{DMU}$,

$\varepsilon:$ a sufficiently small positive number

$\mu_{0}$ : variable that related to returned scale direction

In the next section, section 5, case study, data collection process, and findings of the study was discussed. 


\section{CASE STUDY AND FINDINGS}

This paper focuses on the application, which was conducted in a food company located in Izmir, Turkey. The reason to select a food company is the critical importance of information traceability within a food supply chain.

If the products pose a threat and/or danger to human health, they can be traced backwards to identify the source, cause, and responsible unit of the problem. Traceability, in general, helps take the necessary precautions, monitor forward to collect the products that pose danger and/or threat, and make hazard analysis for critical control points (Aung \& Chang, 2014). It is critical as a support tool in product safety and quality by ensuring the realization and sustainability of their plans (Prashar et al., 2020).

Similarly, food traceability is one of the most basic tools in ensuring food safety. In the framework for transparency, there is a need to determine the source of the problem by monitoring the products and processes backwards when any undesired situation occurs. Furthermore, it is an approach that aims to establish the necessary information system for crisis management mechanisms such as forward monitoring and recovery (Mishra et al., 2020). Thanks to the traceability, the principles of transparency and traceability provide improvements such as food safety, prevention of food fraud, and food quality (Charlebois \& Haratifar, 2015). Moreover, with the adaptation of traceability and transparency in food supply chains, and since traceability and transparency create knowledge, organization information can reach traceability (Behnke \& Janssen, 2020; Martinec \& Pavkovic, 2014). Therefore, to avoid these mentioned problems such as food security, food quality, food fraud, it is aimed to measure information transparency of suppliers.

The case company is devoting upmost importance to transparency and food security in its supply chains. They aim to manage the information transparency in supply chains with their suppliers. The company has willing and is decisive on making necessary investments and allocation to establish a transparent and sustainable supply chain with their suppliers to reach the ultimate aim of food security. In that sense, the company believes that such a transparency may not only increase transparency, efficiency, and trust among suppliers; but also contributes to their competitiveness due to the fact that such a competency cannot be easily imitated by its competitors. Therefore, as a case, a company performing in a food supply chain network was chosen.

The proposed framework is generic, and applicable to similar studies where information transparency on other industries are studied; however, the results are unique and shall not be generalized.

In the data collection process, data were gathered through pairwise comparisons. Pairwise comparisons were conducted with the permission and approval of the Board of Directors. Five authorities carried out pairwise comparisons; the information manager, the supply chain manager, the vice information manager, the vice supply chain manager, and the member of the executive board, who are responsible for information technology and management within the company. The sample size of five for the data gathering process is applicable as can be seen in other studies following a similar procedure (Sivakumar et al., 2018; Xia et al., 2015).

The authorities have been determined as experts due to their experience $(14,16,12,14$, and 22 years, respectively). Table 3 shows information about company experts.

The weights of the main criteria can be seen in Table 4. These weights were found by applying the step-by-step formation of Fuzzy ANP. Firstly, pairwise comparisons were established to identify the relations among criteria. Then, the initial supermatrix is formed to present the relative importance of cluster $\mathrm{k}$ to cluster 1 . Then, weighted supermatrix is calculated. Finally, the limit supermatrix is obtained through taking power of weighted supermatrix until all values for same row will be same. After all values are normalized, then the weights were found as can be seen in Table 4 .

According to Table 4, most important criterion for information transparency was found as Content with a weight of 0.33 , followed by Scope, and Comprehensiveness with weights of 0.23 , and 
Table 3. Information about Company Experts

\begin{tabular}{|c|c|c|c|c|}
\hline Expertise & Department & $\begin{array}{l}\text { Number of years of } \\
\text { experience in the Company }\end{array}$ & $\begin{array}{l}\text { Total Work } \\
\text { Experience in Years }\end{array}$ & Gender \\
\hline Information Manager & Information Technology & 8 & 14 & Male \\
\hline Supply Chain Manager & Supply Chain & 10 & 16 & Male \\
\hline Vice Information Manager & Information Technology & 7 & 12 & Female \\
\hline $\begin{array}{l}\text { Vice Supply Chain } \\
\text { Manager }\end{array}$ & Supply Chain & 7 & 14 & Female \\
\hline $\begin{array}{l}\text { Member of the Executive } \\
\text { Board }\end{array}$ & Management & 22 & 22 & Female \\
\hline
\end{tabular}

Table 4. Weights of Criteria

\begin{tabular}{|l|l|}
\hline Criteria & Weights \\
\hline Comprehensiveness & 0.19 \\
\hline Regularity & 0.08 \\
\hline Timeliness & 0.10 \\
\hline Content & 0.33 \\
\hline Scope & 0.23 \\
\hline User-friendliness & 0.07 \\
\hline
\end{tabular}

0.19 , respectively. Analysis of the results demonstrated that Content, Scope and Comprehensiveness dimensions has $75 \%$ impact on the transparency of data. Remaining 25 percent is affected by Timeliness, Regularity and User-friendliness.

Table 5 shows the efficiency scores for each alternative. These alternatives were suppliers of the company, and were evaluated with respect to information transparency regarding 43 inputs using DEA.

Table 5. Efficiency Scores for Each Alternative

\begin{tabular}{|l|l|l|l|l|l|l|l|l|l|}
\hline $\mathbf{A 1}$ & 1 & $\mathbf{A 1 2}$ & 0.64 & $\mathbf{A 2 3}$ & 0.67 & $\mathbf{A 3 4}$ & 0.69 & $\mathbf{A 4 5}$ & 0.84 \\
\hline $\mathbf{A 2}$ & 0.74 & $\mathbf{A 1 3}$ & 1 & $\mathbf{A 2 4}$ & 1 & $\mathbf{A 3 5}$ & 1 & $\mathbf{A 4 6}$ & 0.7 \\
\hline $\mathbf{A 3}$ & 0.8 & $\mathbf{A 1 4}$ & 0.88 & $\mathbf{A 2 5}$ & 0.75 & $\mathbf{A 3 6}$ & 0.78 & $\mathbf{A 4 7}$ & 0.86 \\
\hline $\mathbf{A 4}$ & 1 & $\mathbf{A 1 5}$ & 0.79 & $\mathbf{A 2 6}$ & 0.74 & $\mathbf{A 3 7}$ & 0.79 & $\mathbf{A 4 8}$ & 0.66 \\
\hline $\mathbf{A 5}$ & 0.83 & $\mathbf{A 1 6}$ & 0.7 & $\mathbf{A 2 7}$ & 0.85 & $\mathbf{A 3 8}$ & 0.85 & $\mathbf{A 4 9}$ & 0.89 \\
\hline $\mathbf{A 6}$ & 0.88 & $\mathbf{A 1 7}$ & 0.89 & $\mathbf{A 2 8}$ & 0.78 & $\mathbf{A 3 9}$ & 0.84 & $\mathbf{A 5 0}$ & 0.91 \\
\hline $\mathbf{A 7}$ & 0.74 & $\mathbf{A 1 8}$ & 0.7 & $\mathbf{A 2 9}$ & 0.95 & $\mathbf{A 4 0}$ & 0.79 & $\mathbf{A 5 1}$ & 1 \\
\hline $\mathbf{A 8}$ & 0.83 & $\mathbf{A 1 9}$ & 0.68 & $\mathbf{A 3 0}$ & 0.62 & $\mathbf{A 4 1}$ & 0.89 & $\mathbf{A 5 2}$ & 0.89 \\
\hline $\mathbf{A 9}$ & 0.89 & $\mathbf{A 2 0}$ & 0.8 & $\mathbf{A 3 1}$ & 0.9 & $\mathbf{A 4 2}$ & 0.75 & $\mathbf{A 5 3}$ & 0.71 \\
\hline $\mathbf{A 1 0}$ & 0.76 & $\mathbf{A 2 1}$ & 0.75 & $\mathbf{A 3 2}$ & 0.71 & $\mathbf{A 4 3}$ & 0.78 & $\mathbf{A 5 4}$ & 0.74 \\
\hline $\mathbf{A 1 1}$ & 0.73 & $\mathbf{A 2 2}$ & 0.66 & $\mathbf{A 3 3}$ & 0.79 & $\mathbf{A 4 4}$ & 0.78 & $\mathbf{A 5 5}$ & 0.79 \\
\hline
\end{tabular}


The results for 55 suppliers indicate that 6 of them are highly efficient (1) in terms of information transparency whereas 13 of them, between $0.85-0.99$, are claimed as partially efficient and the rest 36 suppliers are considered as inefficient within information flows in terms of transparency. Figure 2 also shows efficiency scores for each alternative.

According to Table 5 and Figure 2, the efficiency scores of alternatives 1, 4, 13, 24, 35, and 51 were found as 1 , which means these alternatives were the most efficient one with respect to information transparency regarding 43 inputs. As a result, approximately $11 \%$ of the suppliers were identified as efficient, and approximately $24 \%$ of the suppliers were identified as partially efficient. Whereas, the $65 \%$ of the suppliers were identified as inefficient in terms of information transparency. The results have been further discussed with the top management and the supply chain managers of the company. They have confirmed the list of efficient suppliers. Thus, the applicability of the proposed framework has been validated by the managers of the company.

Figure 2. Efficiency Scores for Each Alternative

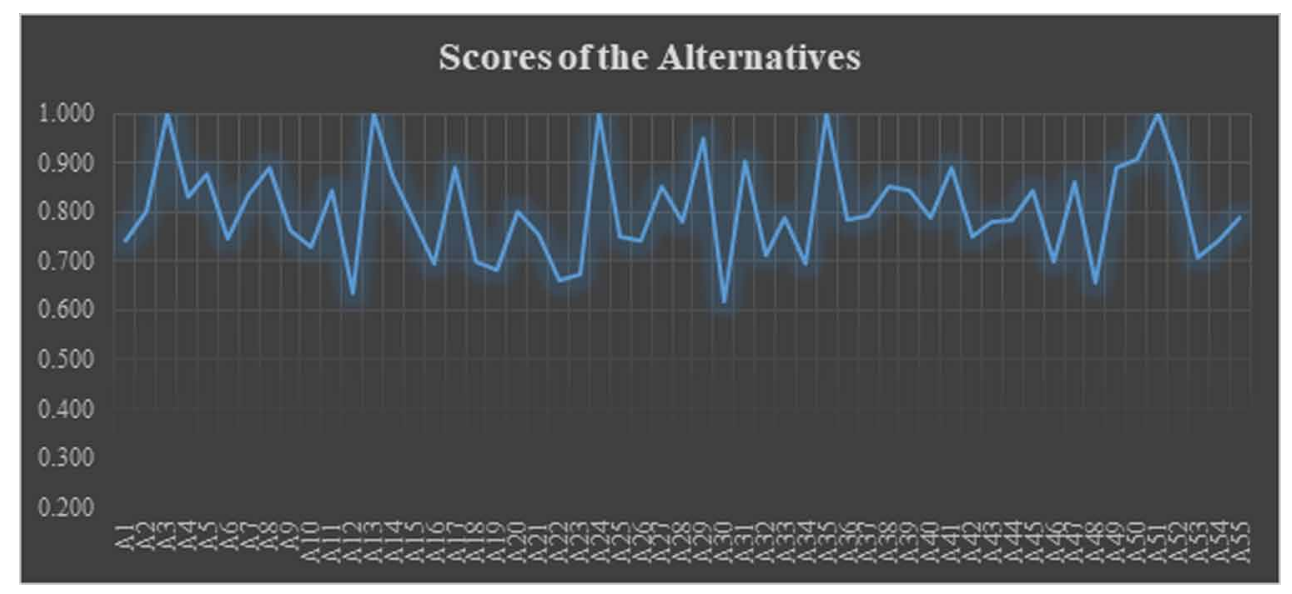

\section{DISCUSSION AND IMPLICATIONS}

Williams (2015) noted that there is no generally-accepted transparency index in a wide extent. For this reason, although the nature of big data is complex, there is a need for developing a framework to reach a concurrence about information transparency. In order to develop a framework for information transparency, some issues, i.e. information transparency dimensions, transparency measurement, data processing technologies are need to be studied in details. Previous studies focused on different aspects of framework development. "Transparency score" concept was developed for measuring the level of transparency to determine how much transparency was available for the users. It is calculated using several aspects of transparency with a scalar, or vector risk measures such as calculating risk scores of security and privacy (Bertino et al., 2019b).

Transparency of information flows through the supply chain can be evaluated as a crucial for competitive advantage. It affects the buying behavior of young generation due to the sensitivity on environmental issues (Kanchanapibul et al., 2014). Successful companies employ strategies responding to the expectations of wider stakeholder groups. Similarly, information transparency can balance the pressure from supply chain partners in socially responsible supply chains to while improving the companies' reputations. Transparency in financial, quality, logistics, after sale services, and origins of materials create good business environment for all stakeholders (Chen \& Voigt, 2020). 
Consumers no longer want to use their time for waiting and walking along the aisles of shopping centers. The search for convenience and transparent information has driven many buyers to provide their grocery needs online. Customer demand for transparency is another prevailing trend driving buyer behavior.

Many buyers easily would change the brand they habitually purchase to another brand that gives more in-depth and detailed product information, more than information on the label. This transparent data driver must be considered by the companies, which want to keep and develop their market position simply by providing transparent data according to the criteria defined and proposed in this study.

\subsection{Academic, Managerial and Practical Implications}

The information transparency presents several benefits for managers. The supply chains are established both on technical and managerial aspects. One of the managerial aspects in a successful supply chain is the trust among the partners of the supply chains. Trust or trustworthiness has a complex structure to manage and quantify. On the other hand, achieving to be a trusted supply chain partner brings benefits and contributes to their competitiveness. The concepts of information sharing and transparency are crucial to able to achieve a trusted supply chain partner position in the supply chain. Thus, the management and control information play an important role. Therefore, the information transparency should be managed, and in order to be managed it should be quantified. In addition to that, supply chains are expanding and turn into a global network with many companies all over the world. These companies are becoming partners in the supply chains with their various origins, backgrounds and cultures that reveals the need for transparency. The supply chain management should be conducted in a comparative manner due to the network structure of supply chains which are extending its size day by day. In such a cosmopolite network the trust is becoming much more difficult to manage and necessitates the management of information transparency.

In that sense this paper proposes a framework for measuring information transparency and enables managers to compare the information transparency of various partners or even stakeholders among their supply chains.

The supplier relationship management have been widely used among companies. Thus, information transparency should be an important part of it. Supplier selection, improvement and termination decisions can be given according to the outputs. Hence, the supplier management activities can be based on information transparency with a quantitative and comparative structure.

The basis of performance management should be structured with transparent information. Thus, there is a need for transparent information for performance management. The managers can easily implement the proposed framework to performance assessment and evaluation of their suppliers.

Today consumers have an advantage of using global data communication services, which stimulate our needs and requirements for getting difficult to meet. The proposed framework can be used to emphasize the highest possible standard in consumer loyalty and protection. Customer Relationship Management systems will be more effective with the transparent data influence to improve customer confidence and loyalty.

Transparency within an organization generates a more collaborative and productive work environment and employee relations. Because when all business activities are performed within transparent information system, everybody are able to see what was done, who performed specific tasks, and which tasks are to be completed. This transparency empowers each unit access transparent information they need for performing their jobs better. All activities will be traceable and managerial accountability would be provided.

The gap between theory and practice necessitates developing theoretical contributions like the proposed framework of this study that provide the basis for transparency need. Transparency is a need, and can be best understood in the context of communication theory that excessively make simple and visible the complexities of today's business world, government, and the public. 
The proposed framework can be taken as the basis to generate, collect, verify and validate the data used and collected among the supply chains. The companies can use it as a guide for data management. The dimensions of the proposed framework can also be analyzed individually to reveal the managerial implications;

Timeliness is an important part of information transparency. As the leading competitive strategies are shifting to responsiveness the need for timeliness has a vital contribution to the competitive strategy. The impact of digitalization and Industry 4.0 necessitates the need for timely and mostly real time data. This is becoming the main component of the digital supply chains and, timeliness is becoming a vital input for it. Thus, the responsive and detail supply chains cannot be achieved without managing the timeliness performance of the information.

The concept of User-friendliness within information management is also contributing to the effectiveness of the company. As the degree to achieve the User-friendliness within the information increases, the following actions; setting, understanding, conceptualizing and implementing a certain task or activity among the supply chain becomes easier. Hence, the degree to achieve the desired goal, so called effectiveness, improves.

Systematicness, with its sub-dimensions of comprehensiveness and regularity, enables managers to achieve a holistic approach in their decisions supported with the systematic data as the main component. The increase of the vertical and horizontal integrations in the supply chains also requires the implementation of holistic view. In addition to that, as mentioned before, the expanding structures of global supply networks can only be managed with holistic approach where the proposed study enables managers to embrace the system with comprehensive and regular information.

Completeness can contribute especially to quality of supply chain operations. The completeness of the information with content and scope can support the conformance to requirements and specifications. The completeness of the information can further contribute to the differentiation strategy, as a competitive strategy, in terms of designing, producing and distributing products in a unique way.

\section{CONCLUSION}

It is clear that information transparency is completely vital to supply chain performance. Not only does this lead to a better business performance, but awareness and trustworthiness also improve social wellbeing of all stakeholders. This research aimed to develop a framework to identify transparency of information in terms of more measurable factors. Based on a quantitative and qualitative analysis of transparency dimensions and factors effective on these dimensions, it can be concluded that Content, Scope and Comprehensiveness are important to consider when designing and targeting supplier relationship systems. The results for 55 suppliers indicate that 6 of them (suppliers 1, 4, 13, 24, 35, and 51) are highly efficient in terms of information transparency. Results indicate that next 13 suppliers (suppliers 6, 9, 14, 17, 27, 29, 31, 38, 41, 47, 49, 50, 52) are also partially efficient (efficiency score is greater than or equal to $85 \%$ ). It can be concluded that applicability of the proposed framework to measure information transparency is at acceptable levels. By analyzing expert opinions of the managers for information flows through the DEA BCC input-oriented model and final outcomes have shown how data transparency measured in a quantitative framework.

The implications about managerial perspectives, supplier relationship management, the basis for performance assessment, timeliness, user-friendliness, systematicness, and completeness were developed.

Based on the framework and conclusions, practitioners should benefit the proposed framework and it can be taken as the basis to generate, collect, verify and validate the data used and collected among the supply chains. The companies can use it as a guide for data management.

This study considers an implementation in Turkey, an emerging economy, which can be identified as the limitation of this study. The findings may change when the implementation is applied to a 
developed country. Also, another limitation is that the data used in this study include subjective judgments.

This study has shown that such a comprehensive framework contributes for the studies of both academics and practitioners by providing a scientific basis to conduct analysis for different cases. Further possible research may focus on the implementation of the proposed framework in other emerging economies. Also, to better understand the implications of the framework, future studies could be done and further research is needed to determine the causes and effects relationship between transparency and supply chain performance. 


\section{REFERENCES}

Al-Jabri, I. M., \& Rostocki, N. (2015). Adoption of ERP systems: Does information transparency matter? Telematics and Informatics, 32(2), 300-310. doi:10.1016/j.tele.2014.09.005

Aung, M. M., \& Chang, S. Y. (2014). Traceability in a food supply chain: Safety and quality perspectives. Food Control, 39, 172-184. doi:10.1016/j.foodcont.2013.11.007

Bach, M. P., Omazic, M. A., \& Zoroja, J. (2015). Transparency as a precondition of systemic behavior: The case of European retailing banks regarding social responsibility communication. Systems Research and Behavioral Science, 32(2), 256-264. doi:10.1002/sres.2267

Banker, R. D., Charnes, A., \& Cooper, W. W. (1984). Some models for estimating technical and scale inefficiencies in data envelopment analysis. Management Science, 30(9), 1078-1092. doi:10.1287/mnsc.30.9.1078

Bartlett, P. A., Julien, D. M., \& Baines, T. S. (2007). Improving supply chain performance through improved visibility. International Journal of Logistics Management, 18(2), 294-313. doi:10.1108/09574090710816986

Bastian, J., \& Zentes, J. (2013). Supply chain transparency as a key prerequisite for sustainable agri-food supply chain management. International Review of Retail, Distribution and Consumer Research, 23(5), 553-570. doi $: 10.1080 / 09593969.2013 .834836$

Behnke, K., \& Janssen, M. F. W. H. A. (2020). Boundary conditions for traceability in food supply chains using blockchain technology. International Journal of Information Management, 52, 101969. doi:10.1016/j. ijinfomgt.2019.05.025

Berggren, E., \& Bernshteyn, R. (2007). Organizational transparency drives company performance. Journal of Management Development, 26(5), 411-417. doi:10.1108/02621710710748248

Bertino, E., Kundu, A., \& Sura, Z. (2019b). Data Transparency with Blockchain and AI Ethics. Journal of Data and Information Quality, 11(4), 16. Advance online publication. doi:10.1145/3312750

Bertino, E., Merrill, S., Nesen, A., \& Utz, C. (2019a). Redefining data transparency-A multi-dimensional approach. IEEE Computer, 52(1), 16-26. doi:10.1109/MC.2018.2890190

Beulens, A. J. M., Broens, D.-F., Folstar, P., \& Hofstede, G. J. (2005). Food Safety and Transparency in Food Chains and Networks Relationships and Challenges. Food Control, 16(6), 481-486. doi:10.1016/j. foodcont.2003.10.010

Bigné, E., Chumpitaz, R., \& Curras, R. (2010). Alliances Between Brands and Social Causes: The Influence of Company Credibility on Social Responsibility Image. Journal of Business Ethics, 96(2), 169-186. doi:10.1007/ s10551-010-0461-x

Boström, M., Jönsson, A. M., Lockie, S., Mol, A. P. J., \& Oosterveer, P. (2015). Sustainable and responsible supply chain governance: Challenges and opportunities. Journal of Cleaner Production, 107, 1-7. doi:10.1016/j. jclepro.2014.11.050

Bushman, R. M., Piotroski, J. D., \& Smith, A. (2004). What determines corporate transparency? Journal of Accounting Research, 42(2), 207-252. doi:10.1111/j.1475-679X.2004.00136.x

Charlebois, S., \& Haratifar, S. (2015). The perceived value of dairy product traceability in modern society: An exploratory study. Journal of Dairy Science, 98(5), 3514-3525. doi:10.3168/jds.2014-9247 PMID:25722000

Charnes, A., Cooper, W. W., \& Rhodes, E. (1978). Measuring the efficiency of decision making units. European Journal of Operational Research, 2(6), 429-444. doi:10.1016/0377-2217(78)90138-8

Chen, X., \& Voigt, T. (2020). Implementation of the Manufacturing Execution System in the food and beverage industry. Journal of Food Engineering, 278, 109932. doi:10.1016/j.jfoodeng.2020.109932

Chi, L.-C. (2009). Do transparency and disclosure predict firm performance? Evidence from the Taiwan Market. Expert Systems with Applications, 36(8), 11198-11203. doi:10.1016/j.eswa.2009.02.099

Coombs, T. W., \& Holladay, S. J. (2013). The pseudo-panopticon: The illusion created by CSR related transparency and the internet. Corporate Communications, 18(2), 212-227. doi:10.1108/13563281311319490 
Coronel, S. (2012). Measuring openness: a survey of transparency ratings and the prospects for a global index. Retrieved from: http://www.freedominfo.org/2012/10/measuring-openness-a-survey-of-transparency-ratingsand-the-prospects-for-a-global-index/

Cullier, D., \& Piotrowski, S. J. (2009). Internet information-seeking and its relation to support for access to Government Records. Government Information Quarterly, 26(3), 441-449. doi:10.1016/j.giq.2009.03.001

Das Neves, J. C., \& Vaccaro, A. (2013). Corporate transparency: A perspective from Thomas Aquinas' Summa Theologiae. Journal of Business Ethics, 113(4), 639-648. doi:10.1007/s10551-013-1682-6

Dev, N., Caprihan, R., \& Swami, S. (2013). Strategic positioning of inventory review policies in alternative supply chain networks: An information-sharing paradigm perspective. International Journal of Logistics Research and Applications, 16(1), 14-33. doi:10.1080/13675567.2013.767324

El-Mahgary, S. (1995). Data envelopment analysis. OR Insight, 8(4), 15-22. doi:10.1057/ori.1995.21

Florini, A. (2000). Does the invisible hand need a transparent glove? In Proceedings of the 11th Annual World Bank Conference on Development Economics. The World Bank.

Francisco, K., \& Swanson, D. (2018). The Supply Chain Has No Clothes: Technology Adoption of Blockchain for Supply Chain Transparency. Logistics, 2(1), 2. doi:10.3390/logistics2010002

Hollyer, J., Rosendorff, B. P., \& Vreeland, J. R. (2011). Democracy and transparency. The Journal of Politics, 73(4), 1191-1205. doi:10.1017/S0022381611000880

Hollyer, J. R., Rosendorff, B. P., \& Vreeland, J. R. (2014). Measuring Transparency. Political Analysis, 22(4), 413-434. doi:10.1093/pan/mpu001

Hung, W. H., Ho, C. F., Jou, J. J., \& Tai, Y. M. (2011). Sharing information strategically in a supply chain: Antecedents, content and impact. International. Journal of Logistics Research and Applications, 14(2), $111-133$. doi:10.1080/13675567.2011.572871

Hung, W. J., Lin, C., \& Ho, C. (2014). Sharing information in a high uncertainty environment: Lessons from the divergent differentiation supply chain. International Journal of Logistics Research and Applications, 17(1), 46-63. doi:10.1080/13675567.2013.837156

Islam, R. (2006). Does more transparency go along with better governance? Economics and Politics, 18(2), 121-167. doi:10.1111/j.1468-0343.2006.00166.x

Kanchanapibul, M., Lacka, E., Wang, X., \& Chan, H. K. (2014). An empirical investigation of green purchase behaviour among the young generation. Journal of Cleaner Production, 66, 528-536. doi:10.1016/j. jclepro.2013.10.062

Kazancoglu, Y., Sagnak, M., Kayikci, Y., \& Mangla, S. K. (2020). Operational Excellence in a Green Supply Chain for Environmental Management - a Case Study. Business Strategy and the Environment, 29(3), $1532-1547$. doi:10.1002/bse. 2451

Khan, M., Lee, H. Y., \& Bae, J. H. (2019). The Role of Transparency in Humanitarian Logistics. Sustainability, 11(7), 2078. doi:10.3390/su11072078

Kumar, R. S., \& Pugazhendhi, S. (2012). Information Sharing in Supply Chains: An Overview. Procedia Engineering, 38, 2147-2154. doi:10.1016/j.proeng.2012.06.258

Kumaraswamy, K. S. N., \& Chitale, C. M. (2012). Collaborative knowledge sharing strategy to enhance organizational learning. Journal of Management Development, 31(3), 308-322. doi:10.1108/02621711211208934

Lazarus, H., \& McManus, T. (2006). Transparency Guru: An interview with Tom McManus. Journal of Management Development, 25(10), 923-936. doi:10.1108/02621710610708559

Martinec, T., \& Pavkovic, N. (2014). Visualization of Information Traceability in Product Development. Paper presented in International Design Conference - Design 2014, Dubrovnic, Croatia.

Maskey, R., Fei, J., \& Nguyen, H.-O. (2019). Critical factors affecting information sharing in supply chains. Production Planning \& Control. doi:10.1080/09537287.2019.1660925 
Minami, C., Nishioka, K., \& Dawson, J. (2012). Information transparency in SME network relationships: Evidence from a Japanese hosiery firm. International Journal of Logistics Research and Applications, 15(6), 405-423. doi:10.1080/13675567.2012.749848

Mishra, N., Mistry, S., Choudhary, S., Kudu, S., \& Mishra, R. (2020). Food Traceability System Using Blockchain and QR Code. In IC-BCT 2019. Blockchain Technologies. Springer. doi:10.1007/978-981-15-4542-9_4

Mulgan, R. (2007). Truth in government and the politicization of public service advice. Public Administration, 85(3), 569-586. doi:10.1111/j.1467-9299.2007.00663.x

Narwane, V.S., Raut, R.D., Mangla, S.K., Gardas, B.B., Narkhede, B.E., Awasthi, A., \& Priyadarshinee, P. (2020). Mediating role of cloud of things in improving performance of small and medium enterprises in the Indian context. Annals of Operations Research. 10.1007/s10479-019-03502-w

Oweis, K. A., \& Dekhili, H. (2019). The transparency of accounting information and its role in making investment decision (Companies listed on the Saudi stock exchange). International Journal of Advanced and Applied Sciences, 6(8), 16-22. doi:10.21833/ijaas.2019.08.003

Ozden, U. (2008). Veri zarflama analizi (VZA) ile Türkiye'deki vakıf üniversitelerinin etkinliğinin ölçülmesi. İstanbul Üniversitesi İsletme Fakültesi Dergisi, 37(2), 167-185.

PITI. (2018). Environmental Information Disclosure: Moving towards Normalization. Annual Report of Pollution Information Transparency Index (PITI) for 120 Cities. Retrieved from: https://wwwoa.ipe.org.cn// Upload/201904190423050506.pdf

Porter, M. E., \& Kramer, M. R. (2011). The Big Idea: Creating Shared Value. How to Reinvent Capitalism-and Unleash a Wave of Innovation and Growth. Harvard Business Review, 89(1-2), 62-77.

Prashar, D., Jha, N., Jha, S., Lee, Y., \& Joshi, G. P. (2020). Blockchain-Based Traceability and Visibility for Agricultural Products: A Decentralized Way of Ensuring Food Safety in India. Sustainability, 12(8), 3497. doi:10.3390/su12083497

Quinn, A. C. (2003). Keeping the citizenry informed: Early congressional printing and 21st century information policy. Government Information Quarterly, 20(3), 281-293. doi:10.1016/S0740-624X(03)00055-8

Rawlins, B. (2008). Measuring the relationship between the organizational transparency and employee trust. The Public Relations Journal, 2(2), 1-21.

Reylea, H. C. (2009). Federal freedom of information policy: Highlights of recent developments. Government Information Quarterly, 26(2), 314-320. doi:10.1016/j.giq.2008.12.001

Saaty, T. L. (1980). The Analytic Hierarchy Process. McGraw-Hill.

Saaty, T. L. (1996). Decision Making with Dependence and Feedback: The Analytic Network Process. RWS Publications.

Sagnak, M., \& Kazancoglu, Y. (2019). Integrated Fuzzy Analytic Network Process and 0-1 Goal Programming Technique for Enterprise Resource Planning (ERP) Software Selection. Ege Academic Review, 19(1), 75-88.

Sahin, H., \& Topal, B. (2019). Examination of effect of information sharing on businesses performance in the supply chain process. International Journal of Production Research, 57(3), 815-828. doi:10.1080/00207543. 2018.1484954

Shi, Y. W., Chen, P.-K., \& Ye, Y. (2019). Factors for Improving and Moderating a Successful Supply Chain. Journal of Business Economics and Management, 20(1), 20-42. doi:10.3846/jbem.2019.6929

Shuler, J. A., Jaeger, P. T., \& Bertot, J. C. (2010). Implications of harmonizing the future of the federal depository library program within e-government principles and policies. Government Information Quarterly, 27(1), 9-16. doi:10.1016/j.giq.2009.09.001

Simon, C. (2006). Corporate information transparency: The synthesis of internal and external information streams. Journal of Management Development, 25(10), 1029-1031. doi:10.1108/02621710610708685 
Sivakumar, K., Jeyapaul, R., Vimal, K. E. K., \& Ravi, P. (2018). A DEMATEL approach for evaluating barriers for sustainable end-of-life practices. Journal of Manufacturing Technology Management, 29(6), 1065-1109. doi:10.1108/JMTM-08-2017-0164

Stiglitz, J. E. (2000). The contributions of the economics of information to twentieth century economics. The Quarterly Journal of Economics, 115(4), 1441-1478. doi:10.1162/003355300555015

Street, C. T., \& Meister, D. B. (2004). Small business growth and internal transparency: The role of information systems. Management Information Systems Quarterly, 28(3), 473-506. doi:10.2307/25148647

Trienekens, J. H., Wognum, P. M., Beulens, A. J. M., \& van der Vorst, J. G. A. J. (2012). Transparency in Complex Dynamic Food Supply Chains. Advanced Engineering Informatics, 26(1), 55-65. doi:10.1016/j.aei.2011.07.007

Wang, Y., Han, J. H., \& Beynon-Davies, P. (2019). Understanding blockchain technology for future supply chains: A systematic literature review and research agenda. Supply Chain Management, 24(1), 62-84. doi:10.1108/ SCM-03-2018-0148

Williams, A. (2009). On the release of information by governments: Causes and consequences. Journal of Development Economics, 89(1), 124-138. doi:10.1016/j.jdeveco.2008.08.001

Williams, A. (2015). A global index of information transparency and accountability. Journal of Comparative Economics, 43(3), 804-824. doi:10.1016/j.jce.2014.10.004

Williams, C. C. (2005). Trust Diffusion: The Effect of Interpersonal Trust on Structure, Function, and Organizational Transparency. Business \& Society, 44(3), 357-368. doi:10.1177/0007650305275299

Wognum, P. M., Bremmers, H., Trienekens, J. H., van der Vorst, J. G. A. J., \& Bloemhof, J. M. (2011). Systems for Sustainability and Transparency of Food Supply Chains - Current Status and Challenges. Advanced Engineering Informatics, 25(1), 65-76. doi:10.1016/j.aei.2010.06.001

Wood, L. C., Reiners, T., \& Srivastava, H. S. (2017). Think exogenous to excel: Alternative supply chain data to improve transparency and decisions. International Journal of Logistics Research and Applications, 20(5), 426-443. doi:10.1080/13675567.2016.1267126

Xia, X., Govindan, K., \& Zhu, Q. (2015). Analyzing internal barriers for automotive parts remanufacturers in China using grey-DEMATEL approach. Journal of Cleaner Production, 87, 811-825. doi:10.1016/j.jclepro.2014.09.044

Yadav, S., \& Singh, S.P. (2020). An integrated fuzzy-ANP and fuzzy-ISM approach using blockchain for sustainable supply chain. Journal of Enterprise Information Management. 10.1108/JEIM-09-2019-0301

Zhu, K. (2002). Information transparency in electronic marketplaces: Why data transparency may hinder the adoption of B2B exchanges. Electronic Markets, 12(2), 92-99. doi:10.1080/10196780252844535 
Erhan Ada, PhD, has led an impressive career as a professor and administrator in his 40 years working in the higher education. In 1980 he has started his academic career he has studied in several state and private universities as an instructor, he has also been featured several well-known academic publications in operations management, supply chain management, Management information System and Circular Economy. Serving as the Dean at several universities Erhan Ada plays a major role in curriculum development studies for undergraduate and graduate programs in Business. Through his commitment to this role, he has helped IEU University improve international projects funded by EU. Erhan Ada currently works as Full Professor Dr. at Business Administration Management, Yasar University. Erhan does research in Supply chain management, Operations Management and Sustainability.

Muhittin Sagnak has been working as Asst. Prof. Dr. in Izmir Katip Celebi University since 2017. His current research interests are sustainability, supply chain management, operations management, multi criteria decision-making, fuzzy systems, and total quality management.

Yiğit Kazançoğlu currently works as Full Professor Dr. at Logistics Management, Yasar University. Yiğit does research in Supply chain management, Operations Management and Sustainability.

Sunil Luthra is working in the Ch. Ranbir Singh State Institute of Engineering and Technology, Jhajjar, Haryana, India. He has contributed over 180 research papers in international referred and national journals, and conferences at international and national level. He has an excellent research track record (over 250 research impact points; received more than 5,000 citations and H-index -38 on Google Scholar). He has received many Awards and Honours for the research and teaching. He is as a Guest Editor of many reputed journals such Journal of Cleaner Production, Production Planning \& Control, Resources Policy, Resources, Conservation and Recycling and Annals of Operations Research etc. He is reviewing papers for more than 50 reputed journals. He is on editorial board of many reputed journals. He has published 05 books with reputed publishers such as CRC Press and New Age International Publisher Ltd. etc. His domain of interests are Green/Sustainable/Circular Supply Chain Management (GSCM/SSCM/CSCM); Digitization in Supply Chain; Industry 4.0; Internet of Things (IoT) and Smart Cities, etc.

Anil Kumar, PhD, is a Senior Lecturer (Associate Professor) at Guildhall School of Business and Law, London Metropolitan University (LMU), London, U.K. For the last ten years, he has been associated with teaching and research. Before joining LMU, he was Post-Doctoral Research Fellow in area of Decision Sciences at Centre for Supply Chain Improvement, University of Derby, United Kingdom (UK). He earned his Ph.D. in Management Science from ABV-Indian Institute of Information Technology and Management, Gwalior, India. He did his graduation in Mathematics (Hons) and MSc (Mathematics) from Kurukshetra University, India. He earned his Master of Business Administration (MBA) and qualified National Eligibility Test (NET), June 2011. He has contributed over $80+$ research papers in international referred \& national journals, and conferences at the international and national level. He has sound analytical capabilities to handle commercial consultancy projects and to deliver business improvement projects. He has skills and expertise of Advance Statistics Models, Multivariate Analysis, MultiCriteria Decision Making, Fuzzy Theory, Fuzzy Optimisation, Fuzzy Multi-Criteria Decision Making, Grey Theory and Analysis, Machine Learning, Application of Soft-Computing, Econometrics Models etc. His areas of research are sustainability science, green/sustainable supply chain management, customer retention, green purchasing behaviour, sustainable procurement, sustainable development, circular economy, Industry 4.0, performance measurement, human capital in supply chain and operations, decision modelling for sustainable business, and integration of operation area with others areas. 